\title{
8
}
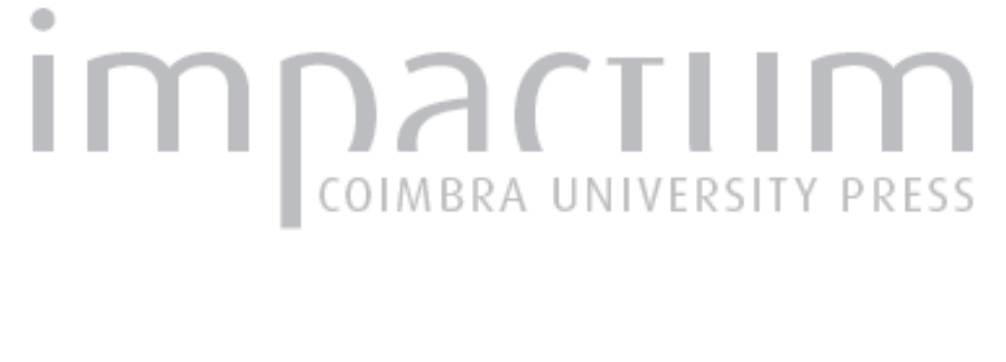

\section{O Conto de Amaro, uma utopia medieval?}

\section{Autor(es): $\quad$ Franco Júnior, Hilário}

Publicado por: Centro de História da Sociedade e da Cultura

URL persistente:

URI:http://hdl.handle.net/10316.2/39423

DOI:

DOI:http://dx.doi.org/10.14195/1645-2259_12_2

Accessed : $\quad$ 26-Apr-2023 11:54:09

A navegação consulta e descarregamento dos títulos inseridos nas Bibliotecas Digitais UC Digitalis, UC Pombalina e UC Impactum, pressupõem a aceitação plena e sem reservas dos Termos e Condições de Uso destas Bibliotecas Digitais, disponíveis em https://digitalis.uc.pt/pt-pt/termos.

Conforme exposto nos referidos Termos e Condições de Uso, o descarregamento de títulos de acesso restrito requer uma licença válida de autorização devendo o utilizador aceder ao(s) documento(s) a partir de um endereço de IP da instituição detentora da supramencionada licença.

Ao utilizador é apenas permitido o descarregamento para uso pessoal, pelo que o emprego do(s) título(s) descarregado(s) para outro fim, designadamente comercial, carece de autorização do respetivo autor ou editor da obra.

Na medida em que todas as obras da UC Digitalis se encontram protegidas pelo Código do Direito de Autor e Direitos Conexos e demais legislação aplicável, toda a cópia, parcial ou total, deste documento, nos casos em que é legalmente admitida, deverá conter ou fazer-se acompanhar por este aviso.

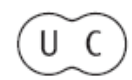


evista de História da Sociedade e da Cultura

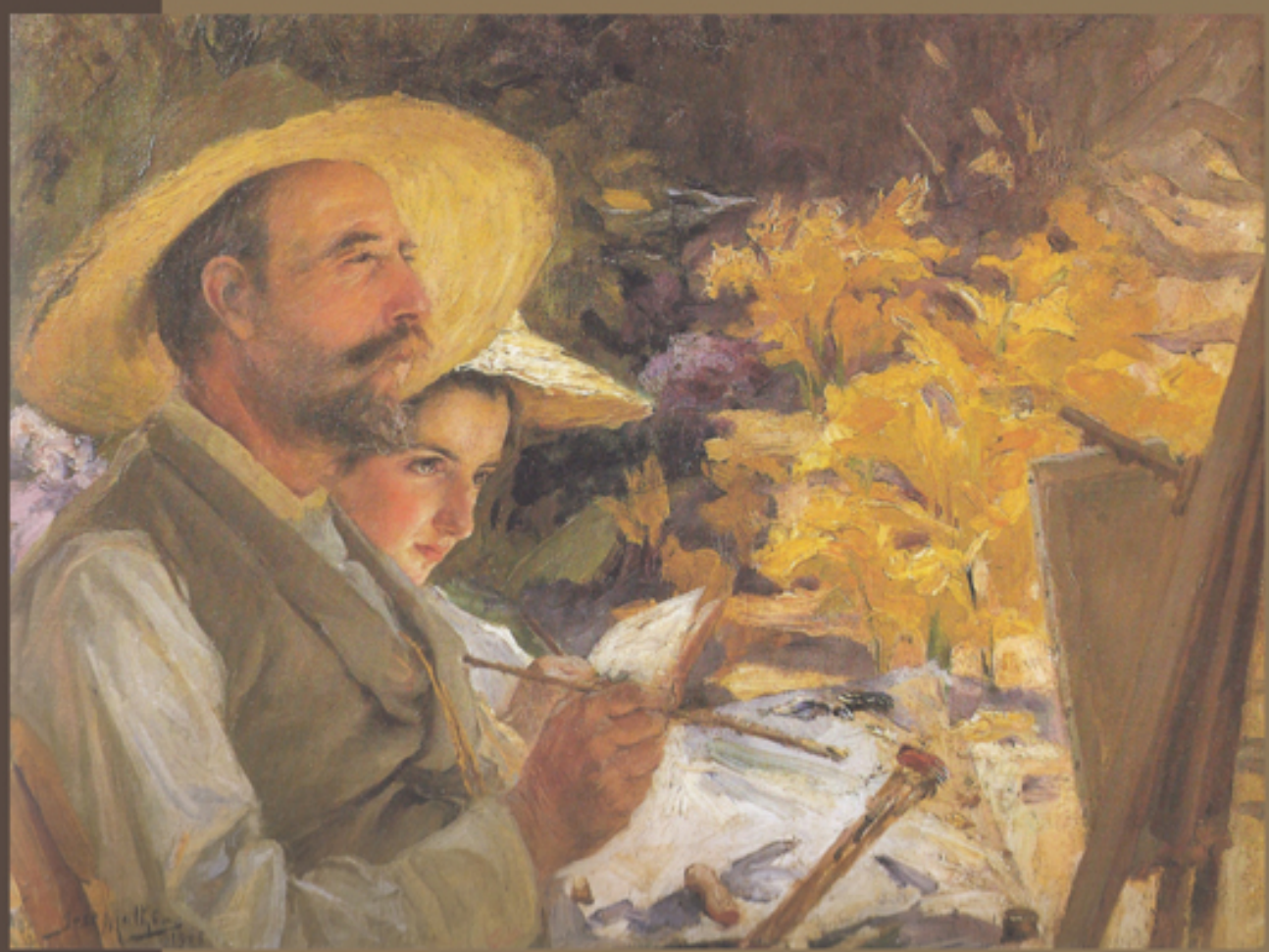

Centro de História da Sociedade e da Cultura Universidade de Coimbra 


\title{
O Conto de Amaro, uma utopia medieval?*
}

\author{
Hilário Franco Júnior \\ Universidade de São Paulo \\ hilario.franco-jr@wanadoo.fr \\ Texto recebido em /Text submitted on: 09/05/2011 \\ Texto aprovado em /Text approved on:29/10/2011
}

\section{Resumo/Abstract:}

Embora muitos entendam que o conceito de utopia não seria válido para a Idade Média, o presente estudo tenta aplicá-lo ao Conto de Amaro que, como a Utopia moreana, descreve uma outopia (lugar nenhum) e uma eutopia (lugar feliz). Descrição que, metaforicamente, parece ser da abadia de Alcobaça onde a narrativa foi produzida em vernáculo português em fins do século XIV.

While to many scholars the concept of utopia would not be valid to the Middle Ages, this study tries to apply it to the Conto de Amaro that, as the More's Utopia, describes a outopia (nowhere) and a eutopia (happy place). It seems a metaphoric description of the Alcobaça Abbey, where the narrative was produced in vernacular Portuguese at the end of the fourteenth century.

Palavras chave/Keywords:

Utopia; Monasticismo; Alcobaça; Amaro.

Utopia; Monasticism; Alcobaça Abbey; Amaro.

* Uma versão inicial deste trabalho foi exposta em 8 de novembro de 2010 no Instituto de Paleografia e Diplomática da Faculdades de Letras da Universidade de Coimbra, graças à iniciativa dos professores doutores Maria Helena da Cruz Coelho e Saul António Gomes, a quem agradecemos a oportunidade. Agradecimento que se estende, igualmente, pelos comentários e sugestões, aos demais colegas e alunos presentes naquele encontro. 
A muitos, a pergunta acima tem resposta negativa óbvia. De fato, argumentam, o gênero literário utópico não nasceu apenas em 1516, com a obra de Tomás Morus? Evidentemente é legítimo estudar os discursos utópicos em si mesmos, verificar sua gênese, suas filiações, seu estilo, sua influência contemporânea e posterior, mas não se pode deixar de lado sua função social. Nenhuma obra literária é autônoma, neutra, isolada, é, sim, produto histórico que expressa, direta ou indiretamente, as condições de sua elaboração. Não se deve minimizar o fato de que os gêneros literários na forma e no conteúdo "designam uma das relações possíveis de um texto com o que lhe é exterior", e assim "colocam em comunicação a literatura com uma sociedade e sua ideologia" distinção entre utopia (gênero literário que descreve uma sociedade feliz imaginária) e utopismo (atitude mental da busca pela perfeição institucional que gera a felicidade social). A rigor, trata-se de distinção reducionista por ver nas utopias obras ficcionais e no utopismo um vago sentimento sem ressonância social.

O fato de a palavra utopia não existir antes de Tomás More não significa que o sentimento utópico não existisse, e sobretudo que não tivesse eficácia sociológica e psicológica. É verdade que vários autores supõem que o peso do cristianismo naquela sociedade teria impedido o despontar de utopias pelo fato de estas desviarem o foco de atenção e de espera do terreno para o celeste. Representante dessa linha, Raymond Trousson pensa que "a utopia recusa a submissão à transcendência". . A vida terrena, no entanto, em especial depois do século XII, não era vista como apenas uma purgação, e sim como obra que deve na medida do possível antecipar e preparar a vida celeste. Cientes disso, alguns estudiosos introduziram nuanças nas suas reticências ao emprego da palavra em relação à Europa medieval. Jacques Le Goff, por exemplo, admite que certas realidades podem ficar um tempo sem serem designadas por uma palavra, cuja gestação é muito variável,

${ }^{1}$ MACÉ, Marielle - Le genre littéraire. Paris: Flammarion, 2004, p. 16.

2 TROUSSON, Utopie et utopisme. em MINERVA, Nadia (ed.), Per una definizione dell'utopia. Metodologie e discipline a confronto. Ravena: Longo, 1992, p. 35 (há tradução brasileira deste artigo em Morus, 2, 2005, p. 123-135). 
em alguns casos longa, como parece ter ocorrido com utopia ${ }^{3}$. De fato, o âmago da palavra está sugerido em Platão, para quem a cidade ideal da República é um projeto (existe apenas no discurso, en logois) ainda sem correspondência concreta por não existir "em nenhum lugar" (oudamou) ${ }^{4}$. Assim, forjar o termo utopia não resultou apenas da genial inspiração de um humanista, e sim de todo um contexto no qual a aceleração das transformações históricas pedia uma ampliação vocabular.

Este contexto acentuou antigos questionamentos existenciais e trouxe à tona novas inquietudes. Quando o filho de Colombo comenta que seu pai tinha cumprido a profecia de Sêneca pela qual "um tempo virá quando o oceano abrirá as barreiras do mundo e se descobrirá uma terra imensa", ele indica que os homens sentiam-se infelizes na sua terra e por isso buscavam outra. Esse estado de espírito de 1492, determinante na criação de 1516, tinha sido também o da segunda metade do século XV, quando foi copiado o único manuscrito que se conhece do Conto de Amaro ${ }^{6}$, e mesmo

3 LE GOFF, L'utopie médiévale: le pays de Cocagne. Revue européenne des sciences sociales. Cahiers Vilfredo Pareto (Genebra), 27, 1989, fascículo 85 (Lumières, utopies, révolutions : espérance de la démocratie. Hommage à Bronislaw Baczko), p. 271. Vários anos depois deste artigo, no qual afirma que teria existido uma única utopia na Idade Média, o grande especialista veio a reconhecer outras expressões utópicas da época: Du ciel sur la terre: la mutation des valeurs du XII au XIII siècle dans l'Occident medieval. em Héros du Moyen Âge, le saint et le roi. Paris: Le Grand Livre du Mois, 2004, p. 1279; L'Europe est-elle née au Moyen Age?, Paris: Seuil, 2003, p. 261; Héros et merveilles du Moyen Age. Paris: Seuil, 2005, p. 19.

4 République, IX, 592ab, ed.-trad. Émile Chambray, Paris, Les Belles Lettres, 1982 (Platon œuvres complètes, VII-2), p. 80, passagem para a qual chamou atenção QUARTA, Cosimo, Livelli del pensiero utopico: antropologia, storia, letteratura. Morus (Campinas), 6, 2009, p. 231.

5 A citação de SÊNECA é de Médée, v. 374-377, ed.-trad. François-Régis Chaumartin, Paris: Les Belles Lettres, 2002, p. 171. O comentário que Hernando Colombo anotou no seu próprio exemplar de Sêneca é fornecido por LUQUE MORENO, Jésus, Tragédias de Seneca. Madri: Gredos, 1987, vol. I, p. 309, n. 95.

${ }^{6}$ Lisboa, Biblioteca Nacional, ms. Alc. 462/CCLXVI. Tal cópia teria sido feita no abaciado de Estêvão de Aguiar (1431-1446), de acordo com CASTRO, Ivo, Vidas de santos de um manuscrito alcobacense. Revista Lusitana (Lisboa), 4, 1982-1983, p. 5-6. Que o sentimento utópico existia no Portugal da época é também o parecer de SILVA, José Manuel Azevedo e, Eva Gomes e o Estado nascente de um novo Paraíso terreal no meio do Atlântico: a Madeira. em O rosto feminino da Expansão portuguesa, Lisboa: Comissão para a Igualdade e Direito das Mulheres, 1994: "naquele mês de maio de 1420 [...] quantas utopias não terão assaltado o imaginário do primeiro grupo de povoadores [...] da Madeira" (p. 391). 
o de fins do século XIV, quando presumivelmente foi composto o relato ${ }^{7}$. Neste, como depois na obra de Morus, primeiro se descreve o mundo a ser superado - ou distopia como se convencionou chamar $^{8}$ - para a seguir se tratar do mundo ideal, utópico.

No caso da narrativa portuguesa, logo que parte em direção ao seu objetivo, o Paraíso terrestre, Amaro enfrenta o "maar cõ tormẽta". Pouco adiante alcança a Ilha dos Cinco Castelos, habitada por gente luxuriosa "e doutras maas condiçoões". Continuando viagem, ele chega à Ilha de Fonte Clara, muito rica e de habitantes bonitos, viçosos, corteses, longevos, mas - o texto não diz por que - pouco indicada para quem anda "a serviço de Deus". Saindo dali, Amaro e seus companheiros ficam presos no "mar coalhado" e cercados por feras marinhas antropófagas, "fortes e esquivas, maiores que cavalos". Depois de escapar desse perigo o navio de Amaro atinge a Ilha Deserta, inabitável devido à grande quantidade de animais selvagens que todo ano na festa de São João Batista se enfrentam em "grande batalha" e de cujos corpos mortos emana grande fedor. Mesmo no mosteiro do Vale das Flores, apesar de toda beleza e religiosidade,

7 A segunda metade do XIV foi a datação proposta por VASCONCELOS, José Leite de, Fabulário português. Revista Lusitana, 9, 1906, p. 105. O último quarto do XIV por HEINEN, Eugen, Die altportugiesische Amaro-Legende. Kritische Ausgabe der ältesten Fassung, Bamberg: Schadel und Wehle, 1973, p. 49. A passagem do século XIV ao XV por Joseph D. H. ALLEN JR, Two Old Portuguese versions of the Life of Saint Alexis. Codices Alcobacenses 36 and 266, Urbana: University of Illinois Press, 1953, p. 5. Os três editores do texto falam no século XIV, sem maior precisão: KLOB, Otto, A vida de sancto Amaro texte portugais du XIV siècle. Romania (Paris), 30, 1901, p. 504; VASCONCELLOS, Laura Remartinez Paes de, Conto de Amaro, edição e estudo de um texto do códice alcobacense 266, Lisboa: Universidade Nova (tese de mestrado datilografada), 1997, p. 19 e 128; SILVA, Elsa Maria Branco da, Conto de Amaro, em NASCIMENTO, Aires Augusto, Navegação de S. Brandão nas fontes portuguesas medievais, Lisboa: Colibri, 1998, apêndice II, p. 261. O texto tem traduções modernas para o alemão (de Elisabeth Zacherl, na série Texte romanischer Volksbücher, 5, Salzburgo, Internationale Arbeitsgemeinschaft für Forschungen zum romanischen Volksbuch, 1979) e o francês (de Laura Vasconcellos, em NUNES, Irene Freire, Récits mythiques du Moyen Âge portugais, Grenoble: ELLUG, 2008, p. 184-215). As citações no presente trabalho são feitas pela edição Silva.

8 O termo foi criado em 1868 por John Stuart Mill, mas difundiu-se a partir de 1920 com o escritor russo Yevgeny Ivanovich Zamyatin, cujo romance censurado em seu país seria publicado em inglês (We) em 1924. Ao exprimir a idéia de perturbação (como em "dispnéia"), privação (caso de "dissimetria") ou separação (por exemplo em "dissidência"), o advérbio dis $(\delta \iota \alpha)$ conota idéia contrária à do adjetivo eus $(\varepsilon v \varsigma)$, de sentido positivo (como em "euforia"). Logo, distopia designa uma utopia negativa, é "lugar onde as coisas não correm bem". 
o sancto homẽ Leomites se queixa "deste mũdo mezquinho, que he rryo de amarguras e lago de treevas e valle de lagrymas, fonte de choro e de planto, thesouro de mizquindade" ". Da distopia (um pouco mais de sete fólios do manuscrito), o herói vai progressivamente (onze fólios) chegando à utopia (sete fólios). Por comparação, na quarta e definitiva edição da obra de Morus - cujo protagonista, como se sabe, é um navegador português - 69 páginas são dedicadas à distopia, 93 à utopia.

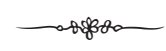

Mas, dir-se-ia com razão, para que a terra de Amaro possa ser efetivamente considerada utópica seria necessário que ela fosse ao mesmo tempo, para recorrer à clássica terminologia moreana, outopia ("lugar nenhum") e eutopia ("lugar feliz"). E, de fato, ela preenche essas duas condições conceituais. De um lado, ela é de localização desconhecida. O fato de o texto situá-la próxima ao Éden não invalida a constatação, pois a região em que este se encontra foi objeto de longos debates durante séculos ${ }^{10}$. Claro que, de acordo com a tradição cristã, imaginava-se o Éden no Oriente, e foi essa direção que Amaro e seus companheiros seguiram. Porém depois de Fonte Clara, além-Mar Vermelho, continuaram navegando por longo tempo sem saber "ja contra quall parte do mũdo eram". Mais adiante, na Ilha Deserta, eles foram aconselhados a navegarem "contra hu nace o sol', contudo mesmo já próximo de sua meta Amaro ouviu de um eremita, questionado por ele sobre a localização do Paraíso terreno, que "nõ o sabe nenhũu hu he"11.

De outro lado, é inegável que o autor anônimo de o Conto de Amaro concebe toda a região em torno do Éden como terra de felicidade. Antes

9 Conto de Amaro, respectivamente $§ 2$, p. 265; §3, p. 266; §4, p. 266; §5, p. 267; §6, p. $269 ; \S 7$, p. 271.

${ }^{10}$ Ainda no século XVII a Academia Francesa incumbiu um de seus membros de estudar a questão, em obra que faria sucesso, com sete edições em onze anos: HUET, Pierre-Daniel, Traitté de la situation du Paradis Terrestre, Paris: Jean Anisson, 1691, $7^{\mathrm{a}}$ ed. Amsterdã, P. Brunet, 1701. Para um resumo dos debates medievais sobre a localização do Éden, DELUMEAU, Jean, Une histoire du Paradis. Le jardin des délices [1992]. Paris: Fayard, 2002, p. 59-97.

${ }^{11}$ Conto de Amaro, §5, p. 267; §6, p. 269; §10, p. 274. 
mesmo de olhar o interior do parayso terreal pelas portas entreabertas, Amaro sentiu-se feliz só de saber que se encontrava ali, e proclamou emocionado que "ja mais nõ veerey coyta nẽ pesar". Quando the foi permitido olhar lá dentro, "vyo tantos prazeres e tantos sabores e tãtos viços, quantos nõ poderya contar nenhũu homẽ do mũdo". Descendo da montanha edênica, em região "das mais bellas terras que no mũdo podya seer", Amaro fundou uma cidade que logo se tornaria "muy grande e muy rryca" 12 . De certa maneira, a condição urbana dessa fundação reforçava seu caráter paradisíaco e utópico. Não se pode esquecer que depois de ter sido imaginado por muito tempo como um jardim, seguindo literalmente a descrição bíblica, o Éden passou em fins da Idade Média a ser geralmente representado como uma cidade. Justamente por ser uma civilização agrária, a Europa ocidental desde o século XII com frequência idealizou a cidade. Conhecido adágio alemão proclamava que "o ar da cidade dá liberdade". O diploma legal através do qual Bolonha libertou seus servos em 1256 foi chamado de Liber paradisus. A sociedade perfeita foi imaginada por Tomás Morus como urbana.

Assim, contra os dois argumentos que negam a existência de utopias na Europa medieval, veremos que, de uma parte, apesar de texto cristão o Conto de Amaro não deixa de imaginar uma sociedade humana perfeita dentro dos limites da imperfeição humana, e, de outra parte, ele não é mera forma literária, exercia uma função social. Sabendo que o único manuscrito conhecido do Conto de Amaro provém do scriptorium de Alcobaça, podemos admitir a origem cisterciense do relato como hipótese inicial para explicar suas características utópicas ${ }^{13}$. Com efeito, a associação monasticismo-utopia é bem admitida pela erudição especializada desde o clássico artigo de Jean Séguy, para quem, considerando que até o século XVI as estruturas monásticas dependiam das estruturas sociais globais, Cister é utopia do

${ }^{12}$ Conto de Amaro, §13, p. 278; §15, p. 280, 281.

${ }^{13} \mathrm{Ou}$ seja, da mesma forma que fontes narrativas podem ajudar a compreender a história cisterciense (conforme reconhece MARQUES, Maria Alegria, A introdução da Ordem de Cister em Portugal, em IDEM, Estudos sobre a Ordem de Cister em Portugal, Lisboa/ /Coimbra: Colibri/Faculdade de Letras da Universidade de Coimbra, 1998, p. 31), o inverso também é verdadeiro: a história cisterciense lança luz sobre a fonte narrativa que é o Conto de Amaro. 
subtipo "cenobitismo feudal" 14 . Sendo produto e produtor do espírito reformista que toma conta da Europa cristã a partir de meados do século XI, o mosteiro borgonhês pretende restaurar o passado. Daí, por exemplo, omitir certos hinos bem aceitos e cantados pelos cluniacenses, substituindo-os por outros vindos da antiga liturgia ambrosiana. Em especial, Cister aspira revigorar o passado não tão distante do modelo beneditino e, através dele, o passado longínquo da sociedade edênica. Todo mosteiro é, nas palavras do principal cisterciense, São Bernardo, "um autêntico Paraíso"15. O fato de os claustros cistercienses terem capitéis quase sempre decorados apenas com motivos vegetais não é simples opção estética, é alusão à perfeição e harmonia do jardim edênico. Simetricamente, todo monge é representação do Adão pré-Queda, daí porque da mesma forma que no Éden ele não havia consumido carne, introduzida na dieta humana apenas depois do Dilúvio, os monges brancos estavam proibidos de comerem carne e gordura intra monasterium $^{16}$. A Ordem de Cister imaginava-se um arquipélago de perfeição no oceano da imperfeição humana.

Ora, a cidade de Trevilles fundada por Amaro é apresentada no conto com alguns dos traços classicamente caracterizadores de uma utopia, e em particular da utopia cisterciense. Primeiro, a cidade amariana tem a pureza do seu herói fundador. Ao contrário das utopias modernas, que de modo geral pensam que sociedade boa gera homem bom, o cristianismo medieval acreditava que homem bom gera sociedade boa. Não é simples detalhe literário que logo na primeira linha do texto Amaro seja definido como homem bõo, e que a sequência da narrativa chame-o em diversas oportunidades de homẽ sancto. Amaro consegue realizar seu "grã desejo de veer o parayso terreall" porque "não é discutindo que se compreende, é pela santidade" ensina São Bernardo, é porque "as coisas espirituais

${ }^{14}$ SÉGUY, Jean, Une sociologie des sociétés imaginées : monachisme et utopie. Annales. Economies. Sociétés. Civilisations (Paris), 26, 1971, p. 328-354 (para a passagem em questão, p. 335-336).

${ }^{15}$ Sermones diversis. XLII,4, ed. LECLERCQ, Jean, TALBOT, Charles e ROCHAIS, Henri, Roma: Editiones Cistercienses, 1963 (S. Bernardi opera, VI-1), p. 258, linha 16.

${ }^{16}$ Gênese, IX,2-3; Capitula cisterciensis ordinis, XIII,2; Instituta Generalis Capituli. XXIV,1, estes dois documentos editados por WADDELL, Chrysogonus, em Narrative and legislative texts from early Cîteaux, Cîteaux: Commentarii cistercienses, 1999 (Studia et Documenta, IX), p. 410 e 466. 
não se mostram em todos os lugares onde acontecem, senão a quem Deus quer", afirma a cisterciense e contemporânea $A$ demanda do santo Graal ${ }^{17}$. Da mesma maneira que nesta narrativa uma voz sugere a Galaaz, Persival e Boorz entrarem em uma barca misteriosa que depois se explica ser "representação da santa Igreja", com a qual correm o mar "como a ventura os levava", Amaro também ouve uma voz ordenar "mete te ẽ hũa nave e vay hu te Deus quiser guyar" 18 .

A pureza é inerente a Amaro e seus companheiros, daí porque se mantém intocada apesar das tentações da grande e rica ilha de Fonte Clara onde se hospedaram por sete semanas. Mesmo assim, para atingir sua meta, a pureza deles precisou ser reforçada pelo caráter purgativo de certos eventos durante a viagem, como a passagem pela pequena ilha inóspita na qual todo ano muitos animais selvagens se entrematavam no dia de São João, a visita à terra maldicta da Ilha dos Cinco Castelos, o amedrontador episódio do mar coalhado ou ainda a curta estadia na ilha chamada Deserta porque tinha sido despovoada "per grandes e esquivas alymaryas que comiã as gentes". A seguir, depois de ter feito quarenta dias de penitência no mosteiro cisterciense Vale de Flores, Amaro tornou-se apto a prosseguir viagem e alcançar, diz-lhe o frade Leomites, "aquilo que queres e desejas". A partir de então, completamente purificados, os viajantes puderam construir sociedades puras. Os companheiros de Amaro estabeleceram-se no Porto de Quatro Casas, onde a pureza era manifesta tanto na natureza (muita água, muita fruta, clima temperado) quanto na população (a "mais formosa gente do mundo"). Continuando sozinho em direção ao Éden, Amaro pernoitou na casa de ermitãos de "vida muito santa" e no mosteiro Flor de Donas conheceu Valides, "dona de muito grande castidade e amiga de Deus", a quem já tinha sido mostrado o Paraíso terreno ${ }^{19}$.

Segundo traço, associado ao anterior, a fraternidade, sob cujo signo se desenrola a viagem inteira de Amaro. Antes de partir, ele "desbaratou

${ }^{17}$ Respectivamente, Conto de Amaro, $\S 1$, p. 265; SÃO BERNARDO, De consideratione. V, XIV, 30 (S. Bernardi opera, III), p. 492, linha 7; A demanda do santo Graal. XXV, 191, ed. MEGALE, Heitor, São Paulo: Companhia das Letras, 2008, p. 193.

${ }^{18}$ Demanda, XXXIX, 250, p. 260 ; LVIII, 410, p. 393; LIX, 421, p. 402; LX, 422, p. 403; Conto de Amaro, §1, p. 265, cf. ainda §2, p. 265; §3, p. 266.

${ }_{19}$ As citações do parágrafo são: Conto de Amaro, §3, p. 266; §6, p. 269; §7, p. 271; §9, p. $273 ; \S 10$, p. $273 ; \S 8$, p. 272. 
todollos bẽes que avya, e deu muito dello aos pobres". No Oriente, próximo da meta, doou aos seus acompanhantes, para "que o partades antre vós", o barco e todo seu conteúdo comprados para a busca do Paraíso. ${ }^{20}$ Embora hierarquicamente desiguais, as relações entre Amaro e seus homens são marcadas pela cumplicidade e pela amizade. A definição recorrente é "companheiros", vocábulo significativo pois como é sabido indica etimologicamente a partilha do alimento essencial (cum panis) e reconforto espiritual ${ }^{21}$. Ainda no plano do vocabulário, há outra presença interessante da preocupação fraternal. $\mathrm{O}$ conto menciona 24 vezes a palavra "mosteiro" e quatro "abadia", porém não utiliza "monge" (cuja primeira atestação é de 1257), preferindo descrever os habitantes de "uma abadia muito grande" como irmitaães, ou falar em "mosteiro de ermitãos" e "mosteiro de frades". Se tanto "monge" quanto "ermitão" evocavam a condição de solidão e isolamento dos indivíduos, o segundo termo adequava-se melhor à vida cisterciense por se referir aos locais ermos escolhidos pela Ordem para erguer suas casas, que explicitadamente deveriam estar distante de cidades, castelos ou aldeias. Se o resumo das decisões do conjunto de abades cistercienses, conhecido por Capitula cisterciensis ordinis, datado provavelmente de 1133, coloca aquela determinação no meio de várias outras - ela é a nona de um total de 26 - para a grande compilação normativa dos arredores de 1147, as Instituta Generalis Capituli, tal regra é a primeira de todas ${ }^{22}$.

O termo preferido, contudo, pelo Conto de Amaro para se referir aos religiosos é "frade", com 16 ocorrências contra 13 de "ermitão". A palavra, atestada desde 1059, traduzia o latim monacus/monachus de acordo com os dois primeiros dicionários de língua portuguesa (um de 1562, outro de 1611), e de fato a Demanda utiliza os dois termos como sinônimos ${ }^{23}$.

${ }^{20}$ Conto de Amaro, §2, p. 265; §12, p. 277.

${ }^{21}$ Raphael BLUTEAU, Vocabulario portuguez e latino, Coimbra, Collegio das Artes da Companhia de Jesus, 1712, vol. 2, p. 412. Jerônimo CARDOSO, Dictionarivm ex lusitanico in latinvm sermonem, Lisboa, João Aluari, 1562, p. 33, dentre outros tipos de companheirismo (sodalis, nos prazeres; socius, no trabalho), indica o do reconforto mútuo, confortis, que aparece doze vezes no Conto de Amaro.

${ }^{22}$ Capitula, IX, 3, p. 408; Instituta, I, 2, p. 458.

${ }^{23}$ MACHADO, José Pedro, Dicionário etimológico da língua portuguesa. Lisboa: Horizonte, $6^{\text {a }}$ ed. 1990, vol. III, p. 83; CARDOSO, Dictionarivm, p. 64; BARBOSA, Agostinho, Dictionarium lusitanicolatinum [1611]. ed. Brian F. Head, Braga: Centro de Estudos Humanísticos-Universidade do Minho, 2007, col. 558; Demanda, por exemplo VIII, 47, p. 57. 
Tratava-se, portanto, de termo muito antigo e amplo para indicar apenas os cistercienses, mas servia perfeitamente para nomear o sentimento e a prática correntes na Ordem. É fato que a fraternidade faz parte do idéario monástico em geral, porém os cistercienses ampliaram-na incluindo os conversos, que embora exercessem as mesmas atividades produtivas dos servos cluniacenses recebiam certo estatuto religioso, tornavam-se "irmãos" dos monges. Em Portugal, como bem viu José Mattoso, Alcobaça divulgou formas de sensibilidade religiosa que anunciavam a dos franciscanos ${ }^{24}$, e entre elas estava a fraternidade. Nada estranho, então, que em certo momento da viagem, entre o Vale das Flores, que já deixara, e o Flor de Donas, onde ainda não chegara, Amaro tenha sido hospedado por ermitãos que o levaram ao vergel (claustro?) onde lhe lavaram os pés. Ora, para a Regra Beneditina que os cistercienses pretendiam restaurar na sua pureza, o mandatum ou lava-pés tal qual realizado e prescrito por Cristo era prática ritual importante, destinada a valorizar a obediência e a humildade em oposição à vontade ${ }^{25}$.

Em terceiro lugar, a terra de Amaro é região de ordem no sentido agostiniano de "disposição de seres iguais e desiguais designados ao lugar que lhes convém" 26 . A boa sociedade não precisa, do ponto de vista medieval, ser igualitária (como pretenderão as utopias posteriores), deve ser bem ordenada. É isso que implanta a unidade necessária ao bom funcionamento social: "onde está a unidade está a perfeição", diz o preceito bernardino. ${ }^{27}$ A idéia de desigualdade na unidade é bem exemplificada pela epístola do Preste João, que circulou por todo Ocidente, inclusive Portugal, onde os cistercienses de Alcobaça em pequeno intervalo de tempo realizaram uma

BLUTEAU, Vocabulario, vol. 4, p. 193, informa que "frade" era forma do vulgo designar religiosos com capuz.

${ }^{24}$ Cluny, cruzios e cistercienses [1982]. em IDEM, Portugal medieval, novas interpretações. Lisboa: Imprensa Nacional-Casa da Moeda, 1992, p. 119.

${ }^{25}$ João, XIII,14-15; La Règle de saint Benoît, XXXV,9, ed. Jean Neufville, trad. Adalbert de Vogüé, Paris: Cerf, 1972 (Sources Chrétiennes, 182), p. 566-567.

${ }^{26}$ De civitate Dei / La cité de Dieu. XIX, 13, ed. Bernhard Dombart e Alfons Kalb, trad. Gustave Combès, Paris, Desclée de Brouwer, 1980 (Euvres de Saint Augustin, 37), p. 110-111. Sobre essa noção no pensamento agostiniano, veja-se BOUTON-TOUBOULIC, Anne-Isabelle, L'ordre caché : la notion d'ordre chez saint Augustin. Paris: Institut d'Études Augustiniennes, 2004.

${ }^{27}$ De consideratione, II, 8, 15, p. 423, linha 24. 
cópia dela e do Conto de Amaro. Ainda que se apresente como senhor dos senhores, soberano de 1072 províncias, e pessoalmente servido por sete reis, cinquenta duques e 375 condes, o Preste João afirma que "não há divisões entre nós" ${ }^{28}$. O manuscrito português da epístola é de fins do século XIV de acordo com seu editor ${ }^{29}$, todavia é provável que o texto já fosse anteriormente conhecido em Alcobaça, pois o mítico personagem tinha sido mencionado pela primeira vez em 1146 por um cisterciense, Oto de Freising, abade de Morimond, casa filha de Claraval, como também seria poucos anos depois Alcobaça. Se os manuscritos não-portugueses da epístola referem-se a um mare coagulatum que não aparece na cópia alcobacense, ele está presente no Conto de Amaro. Se a cópia portuguesa da epístola não fala, como seus congêneres estrangeiros, de uma fonte que permite aos seus usuários viverem até 300 anos de idade, Amaro conhece na ilha de Fonte Clara uma população que cõmunalmẽte vive 300 anos $^{30}$.

A vastidão tanto do império joânico quanto da rede monástica cisterciense pedia um ordenamento que permitisse a convivência positiva entre populações e facções bem distintas. No caso cisterciense, define um texto de meados do século XII, cada unidade é "duo monasteria, unum scilicet laicorum fratrum, et aliud clericorum" ${ }^{31}$. Realmente, na década de 1110 surgira a figura dos conversi, irmãos leigos que moravam nos domínios abaciais, mas fora do claustro, passavam por noviciado de um ano e faziam voto de pobreza, castidade e obediência, porém assistiam aos ofícios divinos

${ }^{28}$ A cópia portuguesa da epístola, intitulada De India et de eius mirabilibus, foi editada e traduzida por MAURÍCIO, Domingos, Ainda a Carta do Preste João das Índias. Brotéria (Braga), 72, 1961, p. 285-303. As passagens aqui citadas são §3, p. 289, linha 26; §4, p. 289, linha 36. Nos manuscritos não portugueses da Epistola presbiteri Johannis, ed. Friedrich Zarncke, em "Der Priester Johannes. Text des Briefes", Abhandlungen der philologischhistorischen Classe der königlich sächsischen Gesellschaft der Wissenschaften (Leipzig), 7, 1879, Preste João é senhor de 72 províncias (\$9, p. 910) e servido além dos reis por 62 duques e 365 condes ( $\$ 14$, p. 293, linhas 182-183). A formulação da unidade também é um pouco diferente nos dois manuscritos, sem que isso prejudique o sentido: "nulla est diuisio inter nos" (ed. Maurício, §9, p. 291, linhas 10-11), "nulla divisio est apud nos" (ed. Zarncke, §46, p. 915).

${ }^{29}$ Lisboa: Biblioteca Nacional de Portugal, cod. Alc. CCLXVI / 462, fol. 111r-123v; MAURÍCIO, Ainda a Carta. p. 287 e 303.

${ }^{30}$ Epistola presbiteri Johannis, C19, p. 911 (mar coalhado); Conto de Amaro, §5, p. 267-268; Epistola, C81, p. 921 (fonte da longevidade); Conto de Amaro, §4, p. 266.

${ }^{31}$ IDUNG DE PRÜFENING, Dialogus duorum monachorum, III, 883-884, ed. Robert Buchard Constantijn Huygens, Studi Medievali (Spoleto), 13, 1972, p. 463. 
apenas aos domingos e nas principais festas religiosas. Da mesma forma que os monges, eles guardavam silêncio enquanto trabalhavam, contudo diferentemente deles não usavam o hábito branco típico dos cistercienses, e sim uma veste acinzentada ou amarronzada. Encarregados de boa parte das tarefas produtivas nas terras monásticas, eles todavia jamais podiam se tornar monges ${ }^{32}$ nem consequentemente participar da eleição do abade. Havia mesmo em todo mosteiro um corredor interno que margeava a galeria ocidental (não por acaso o lado da morte, no simbolismo da época) do claustro evitando que os conversi precisassem passar pelo paradisus claustrali $^{33}$. No conto, ainda que os dezessete homens que partem para o Oriente constituam um grupo unido, ele é claramente desigual: de um lado estão aqueles que o próprio Amaro chama de "meus companheiros e amigos", de outro ele mesmo, definido como "senhor"34.

Quando Bernardo de Claraval faz, em 1124-1125, sua célebre recriminação (depois reiterada várias vezes pela legislação cisterciense) à abundante decoração figurativa usada pelos cluniacenses, é por considerar que tais "ridicula monstruositas" vão contra o ordenamento (ordo) estabelecido por Deus. A representação de toda "deformis formositas ac formosa deformitas" é fator de desordem do espírito, afasta os monges da reflexão ${ }^{35}$. Baseada em tais idéias, "a edificação cisterciense é projeção de um sonho de perfeição moral" avalia Georges Duby. Como Otto von Simson mostrou, Bernardo pensava a arquitetura monástica fundada não em esculturas e pinturas, e sim na luminosidade e proporcionalidade, o que influenciaria o abade Suger na concepção de Saint-Denis, o arcebispo Henrique na da catedral de Sens, o bispo Godofredo na de Chartres. No mesmo contexto espiritual e cultural, um dos palácios do Preste João é descrito como tendo abóbada de reluzentes safiras e brilhantíssimos topázios, colunas cujos enormes carbúnculos

${ }^{32}$ Capitula, XXII,1, p. 412. A condição dos conversos foi definida por um texto específico, o Usus conversorum, elaborado por volta de 1120 e editado por WADDELL, Cistercian lay brothers. Twelfth-century usages with related texts. Cîteaux: Commentarii cistercienses, 2000 (Studia et Documenta, X).

${ }^{33}$ Sobre o simbolismo espacial, JERÔNIMO, Expositio quatuor Evangeliorum (PL 30), col. 549d-550a. Sobre a expressão "Paradisus claustralis", veja-se o capítulo 4 de GILSON, Étienne, La théologie mystique de saint Bernard [1934]. Paris: Vrin, 1980, p. 108-141.

${ }^{34}$ Conto de Amaro, §10, p. 273; §12, p. 277; §14, p. 280; §15, p. 280-281.

${ }^{35}$ Apologia ad Guillelmum abbatem, XII, 29 (S. Bernardi opera, III), p. 106, linhas 14-25. 
permitem iluminar o palácio como o mundo é iluminado pelo $\mathrm{sol}^{36}$. Ora, o castelo paradisíaco avistado por Amaro ainda a meio caminho do topo da montanha revelou-se todo luz e cores, construído em pedras brancas, verdes, vermelhas e pretas. Antes de alcançá-lo, ele encontrou uma edificação muito luminosa porque não tinha muros, toda sua volta era em arcos feitos de cristais e "outras belas pedras", a cobertura de pedras preciosas ${ }^{37}$. O efeito ornamental que ele despertou em Amaro não foi, portanto, muito diferente daquele provocado pela leveza e elegância das formas arquitetônicas das igrejas e claustros cistercienses ou pelas colunas sólidas embaixo e esguias no alto existentes no palácio do Preste João.

Quarto traço utópico que caracteriza a terra de Amaro, a prosperidade. Ao alcançar a montanha em cujo topo se encontra o Paraíso terreno, Amaro viu um castelo todo de mármore e pedras preciosas, o "maior, mais alto e mais belo de quantos no mundo havia", com um perímetro de mais de cinco léguas (28 quilômetros). No meio da subida, Amaro deparou-se com uma construção de pedras preciosas no interior da qual "caberiam quinze mil cavalos" e onde havia quatro fontes belas e ricas, "lavradas em metal". Alcançado o cume da montanha, apesar de insistentes pedidos Amaro não pôde entrar no castelo porque "ainda não é tempo" explicou-lhe o porteiro, que consciente, porém, da santidade do personagem, entreabriu as portas para que ele visse alguma coisa do interior do Paraíso. E assim Amaro vislumbrou "tantos prazeres e tanto sabores", árvores, flores, ervas, maçãs, laranjas, "todas as outras frutas do mundo". Enxergou ainda elegantes fontes, preciosas tendas e moços e moças ricamente vestidos. Quando, à guisa de despedida, o porteiro lhe ofereceu alguma coisa do Éden como lembrança, Amaro escolheu uma vasilha de terra ${ }^{38}$. Descendo para o vale, reuniu pessoas na cidade que tinha sido fundada por seus companheiros de

${ }^{36}$ Respectivamente, Saint Bernard, l'art cistercien [1976]. Paris: Flammarion, 1979, p. 13 e 94; The Gothic cathedral: origins of Gothic architecture and the medieval concept of order. Nova York: Pantheon, 1956 (Bollingen series, 48); De India et de eius mirabilibus, $\S 16$, p. 294, linhas 217-226.

37 Conto de Amaro, $\$ 13$, p. 277. Vertemos por "edificação" aquilo que o relato chama de tenda, devido ao contexto narrativo e também por aquela palavra ter a acepção de livraria, farmácia, oficina (BARBOSA, Dictionarium lusitanicolatinum, col. 1027), podendo, portanto, ser entendida como construção claustral.

${ }^{38}$ Conto de Amaro, §13, p. 277-279. 
viagem enquanto ele visitava o Paraíso, e com elas assentou lá perto uma nova aglomeração em cujo território espalhou a terra edênica, o que permitiu que as árvores crescessem "em um ano mais do que em outro lugar em cinco". Seus habitantes construíram belas casas, plantaram muitas árvores, a cidade tornou-se grande e rica ${ }^{39}$.

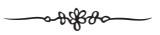

Entretanto, o Conto de Amaro pode, efetivamente, ser considerado cisterciense? Já se notou que aquele texto talvez possa ser interpretado como produto da criação coletiva popular da Idade Média, embora na versão agora conhecida tenha marcas de um autor ou de autores individuais ${ }^{40}$. Ainda que Laura de Vasconcellos não indique que marcas são estas, nem quem poderiam ter sido seus autores, é possível vislumbrar a resposta inspirando-se na observação de Cocheril, "são os cistercienses que fizeram - a palavra não é demasiado forte - a nação portuguesa"41. E com efeito as referências àquela ordem, mesmo que indiretas, abundam no texto.

Por exemplo, quando exalta a hospitalidade que Amaro recebeu em vários momentos (totalizando 246 dias), e que sem ser exclusividade dos cistercienses era tão praticada por eles que em Alcobaça absorvia metade do trigo produzido. Ou quando elogia a beleza do local e os muitos jardins, prados e vergéis do "mosteiro de frades brancos e homens de boa vida", onde Amaro foi abençoado por um monge "pela reverência da Ordem" e

${ }^{39}$ Conto de Amaro, $\$ 15$, p. 280-281. Note-se que a versão castelhana do século XV nada fala do destino que Amaro deu à porção de terra levada do Paraíso: VEGA, Carlos Alberto, Hagiografia y literatura. La vida de San Amaro. Madri: Crotalón, 1987, p. 116-118.

40 VASCONCELLOS, Conto de Amaro, edição e estudo, p. 11.

${ }^{41}$ COCHERIL, Maur, Le problème des fondations cisterciennes au Portugal aux XII et XIII siècles. em Mélanges à la mémoire du père Anselme Dimier. Arbois: Pupillin, 1984, vol. II-4, p. 629. Embora mais reservado, MATTOSO, José, reconhece que a cavalaria, essencial na defesa e na expansão do território, encontrou "na orientação cisterciense um apelo à abnegação e à renúncia que está ligada a uma concepção genérica da função do indivíduo em sociedade", portanto à consolidação de uma consciência nacional: Cluny, cruzios e cistercienses. p. 118. Também MARQUES pensa que o papel dos cistercienses "foi de particular relevância na estruturação do reino de Portugal, desde os aspectos econômicos aos da formação de mentalidades": Estudos, p. 7. 
onde fez uma quarentena de penitência e comungou ${ }^{42}$. Ou quando o relato fala do costume de Amaro levantar antes do amanhecer e ficar "ataa luz em oraçom e nõ tornava mais a dormir", talvez alusão à liturgia cisterciense que inspirada em versículo do Salmo 118 estabelecia uma prece no meio da noite. É o caso ainda de Amaro, desde que a luz era apagada, deixar o bom leito oferecido por seus anfitriões e deitar-se no chão, porque os monges brancos estavam habituados a dormir sobre um catre coberto apenas por fino colchão de palha ${ }^{43}$. Talvez para indicar a condição cisterciense do mosteiro de Flor de Donas, tão importante na narrativa, esta afirma que suas religiosas vestem-se de branco e possuem dezessete moinhos, instrumento bastante empregado por aquela Ordem ${ }^{44}$.

Mais expressivo, para aquele mosteiro dirigia-se três vezes ao ano e lá foi sepultada a segunda mais importante personagem do relato, a santa eremita Valides, definida como "serva da Virgem Santa Maria". Esta, como se sabe, é patrona dos cistercienses cujas igrejas são todas dedicadas a ela: "in honore regine celi et terrae nostra omnia fundari debere cenobia", declaram textos normativos da Ordem. Logo, não é casual que quando se viu ameaçado por feras marinhas no "mar coalhado", Amaro tenha recorrido à Virgem. Nesta longa súplica, o autor retoma muitos dos clássicos elementos do hinário mariano (rainha dos céus, estrela do mar, remédio dos pecadores, castelo forte, advogada, porto, flor preciosa, fonte de bondade, etc), e a seguir descreve detalhadamente a visão que Amaro teve de uma procissão de anjos encabeçada pela Mãe do Rei dos Céus, referida nomeadamente seis vezes ao longo do conto ${ }^{45}$.

${ }^{42}$ Conto de Amaro, $\S 2-4$, p. 266, §6, p. 269, §7, p. 271, §10, p. 273, §11, p. 275, §15, p. 280; SÃO BOAVENTURA, Fortunato de, Historia chronologica e critica da Real Abadia de Alcobaça. Lisboa: Impressão Régia, 1827, p. 45; Conto de Amaro, §7, p. 270-271.

${ }^{43}$ LEKAI, Louis Julius, The Cistercians. Ideals and reality, Kent (Ohio): The Kent State University Press, 1977, p. 364 e 373; Conto de Amaro, §11, p. 275.

${ }^{44}$ Conto de Amaro, §11, p. 275-276; LEKAI, The Cistercians, p. 321.

${ }^{45}$ A menção a "serva da Virgem" está no Conto de Amaro, §8, p. 272. A citação normativa é dos Capitula, IX, 2, p. 408. Com outra redação a mesma decisão aparece nos Instituta, XVIII, 2, p. 463. A oração do Conto de Amaro, §5, p. 267, encontra suas fontes no Analecta Hymnica Medii Aevi [1886-1922], ed. DREVES, Guido Maria e BLUME, Clemens, Nova York / Londres: Johnson Reprint, 1961, 55 volumes. As referências à Virgem no Conto de Amaro são do §5, p. 267-268; §8, p. 272; §9, p. 273; §13, p. 279. 
Também de "marcado cunho cisterciense", na expressão de José Filgueira Valverde, é o tema do tempo suspenso (típico dos relatos utópicos), presente no texto quando Amaro fica às portas do Paraíso admirando as belezas do interior por 267 anos que lhe parecem breves instantes ${ }^{46}$. Estas belezas não eram apenas visuais, o autor insiste sobre a sonoridade do Paraíso. Ali as aves cantam de maneira tão saborosa que se "nõ ouvesse outro viço, aquell avondarya muy bem". Além delas, moços e moças cantam enquanto tocam "guitarras, violas e outros instrumentos". Um cortejo de virgens acompanha a Mãe de Cristo entoando um cântico, e depois que elas se instalam sob uma tenda pousam ali formosas aves com "penas de anjos" que "cantavã milhor que nũca foy homẽ que ouvisse" ${ }^{\text {"47 }}$. Toda esta descrição não parece desconectada com o fato de São Bernardo valorizar a sonoridade, daí aliás ter composto 339 sermões, peças a serem comunicadas oralmente. Para ele, a audição era mais importante que a visão. Nas suas próprias palavras, "o ouvido descobre (invenit) o que os olhos não podem perceber. A aparência atraiçoou os olhos, a verdade penetrou pelo ouvido" 48 . Nada estranho, então, que os cistercienses tenham se preocupado com a sonoridade de seus edifícios. Na igreja abacial de Notre-Dame du Thoronet (consagrada em 1136), por exemplo, a construção teria obedecido a essa filosofia bernardina: a reverberação no edifício tem cerca de quatro segundos e as proporções da construção estão em correspondência com intervalos musicais. A sonoridade encontra-se na base mesma da busca do Paraíso, pois Amaro "nũca folgava se nõ quando ouvya fallar ẽ elle" "49. Diante disso tudo, não surpreende que no relato apareçam 117 vezes verbos do campo semântico da audição e apenas 42 do da visão.

Porque os mosteiros cistercienses são figurações edênicas, as portas do castelo paradisíaco são imensas "como corredura de hũu cavalo",

${ }^{46}$ Tempo y gozo eterno en la narrativa medieval. Vigo: Edicións Xerais de Galicia, 1982, p. $87,92,98$. Sobre o caráter utópico do tempo descrito pelo texto português, tomamos a liberdade de enviar ao nosso Concepts of time in medieval Portugal: temporalities and simultaneities in the Conto de Amaro. Journal of Medieval Iberian Studies (Abingdon, UK),

2, 2010, p. 51-76.

${ }^{47}$ Conto de Amaro, $\$ 13$, p. 278-279.

${ }^{48}$ Sermones super Cantica Canticorum, XXVIII,5 (S. Bernardi opera, I), p. 195, linhas 9-10.

${ }^{49}$ Conto de Amaro, §1, p. 265. 
lembrando que o Éden é a casa de Adão, personagem gigantesca antes do pecado de acordo com relatos míticos de variadas procedências, inclusive muçulmana, bem conhecida em Portuga $1^{50}$. Também falaram nisso fontes cristãs, como um cronista inglês de fins do século XII ou um italiano de meados do século XIV ${ }^{51}$. Porque tudo que Deus fez é bom e belo, o castelo edênico revelado pelo conto dispensa todo elemento ornamental, da mesma forma que faziam os cistercienses nos seus mosteiros, onde a escultura era estritamente proibida (numquam) e a pintura aceita apenas sobre crucifixos de madeira ${ }^{52}$. Esse despojamento que pretendia renovar a tradição monástica, então enfraquecida no julgamento dos cistercienses, significou a adoção de um estilo de vida de singeleza edênica. Sua liturgia estava baseada apenas na oração e na comunhão - foi na abadia cisterciense de Villers-en-Brabant que se celebrou pela primeira vez, em 1252, a nova festa do Corpus Christi - como havia feito Adão ${ }^{53}$ e como faria

${ }^{50}$ Conto de Amaro, $\$ 13$, p. 278; Les aventures de Sindbad. trad. KHAWAN, René Rizqallah, Paris: Phébus, $2^{a}$ ed. 1990, p. 191; Relation des voyages faits par les arabes et les persans dans l'Inde et à Chine dans le IX siècle de l'ère chrétienne, I, 7, ed.-trad. Louis-Mathieu Langlès e Joseph Toussaint Reinaud, Paris: Imprimerie Royale, 1845, vol. I, p. 5-6; ABOU-ZEID AHMED BEN SAHL EL-BALKHI, Le livre de la Création et de l'histoire. 6, ed.-trad. Clément Huart, Paris: Ernest Leroux, 1899, vol. I, p. 179. Além desses três textos do século IX, recolheu a mesma informação em 1356, bem próximo ao conto português, IBN BATTUTA, Voyages. ed.-trad. Charles Defremery e Beniamino Raffaelo Sanguinetti, Paris: La Découverte, 1997, vol. III, p. 265.

${ }^{51}$ WALTER MAP, De Nugis Curialium, I,1, ed. Montague Rhodes James, Oxford: Clarendon, 1914, p. 2; MARIGNOLLI, João de, Cronica Boemorum. I, ed. Joseph Emler, em Fontes rerum Bohemicarum. Praga: Nákladem Musea královstvi českéh, 1882, vol. III, p. 499b.

${ }^{52}$ Capitula, XXVI, 2, p. 413.

${ }_{53}$ Embora o Adão orante esteja ausente do texto bíblico, aparece em apócrifo que teve versão árabe em meados do século VIII: La caverna dei tesori, 20, ed. Margareth Dunlop Gibson, trad. Antonio Battista e Bellarmino Bagatti, Jerusalém: Franciscan Printing Press, 1980 (Studium Biblicum Franciscanum, Collectio Minor, 26), p. 45. Aparece igualmente em uma iluminura realizada em Bruges um pouco antes de 1480, acompanhando a tradução francesa de OVÍDIO, Les metamorfoses. Bibliothèque Nationale de France, ms. fr. 137, fol. 1. Sem ser propriamente a comunhão, mas prefigurando-a, Adão e Eva depois que Deus deixou de lhes falar construíram com pedras um altar sobre o qual depositaram como oferenda ao Senhor uma mistura de folhas, terra e seu próprio sangue, afirma um apócrifo cristão dos séculos VIII-IX: Il combattimento di Adamo, 14, ed.-trad. Antonio Battista e Bellarmino Bagatti, Jerusalém: Franciscan Printing Press, 1982 (Studium Biblicum Franciscanum Collectio Minor, 29), p. 53-55. 
Amaro $^{54}$. A caridade praticada por este logo no começo da narrativa era um dos eixos centrais do despojamento cisterciense, tal qual definido em 1119 pela Carta Caritatis Prior, em 1138 por São Bernardo (que enviaria monges de Claraval para a fundação de Alcobaça) e em 1152 (ano anterior à fundação da abadia portuguesa) pela Carta Caritatis Posterior ${ }^{55}$. Levando-se em conta a importância que a cultura medieval atribuía ao simbolismo numérico, pode-se pensar que não era fortuito o fato de os companheiros de viagem de Amaro serem dezesseis, como o número de dias passados em Flor de Donas, já que no ensinamento paulino tal quantidade indica as virtudes contidas na caridade, uma das qualidades de Valides com quem Amaro conviveu naquele mosteiro ${ }^{56}$.

Semelhantemente ao que ocorrera no jardim dos primeiros tempos, os monges brancos dedicavam-se antes de tudo ao trabalho manual, em especial agrícola, que atualizava a tarefa de Adão de "cultivar e guardar" o Éden. A legislação cisterciense determinava que todo alimento dos monges deveria "provir do trabalho manual, do cultivo da terra, da criação de animais". Não por acaso as iluminuras dos primitivos manuscritos cistercienses mostram monges cortando árvores, colhendo cereais, vindimando, tecendo. Assim como fizeram Amaro e seus companheiros em Trevilles, onde plantaram "muitas vinhas, pomares e hortas" com excelente resultado ${ }^{57}$. Pode-se pensar que a porção de terra levada por Amaro do Éden e responsável por aquela produtividade, segundo o texto literário,

${ }^{54}$ Amaro reza para a Virgem em alto $\operatorname{mar}(\S 5$, p. 267) e antes do alvorecer todos os dias em que esteve em Flor de Donas ( $\$ 11$, p. 275). Ele comunga no mosteiro do Vale das Flores $(\S 7$, p. 271) e em Trevilles, no seu leito de morte ( $\$ 15$, p. 281$)$.

${ }_{55}$ Conto de Amaro, §2, p. 265. O primeiro daqueles documentos cistercienses está publicado e traduzido por WADDELL, Narrative and legislative texts. p. 442-450. O segundo encontra-se em SÃO BERNARDO, Corpus epistolarum, CXLII (S. Bernardi opera, VII), p. 340-341. O terceiro é fornecido por WADDELL, Narrative and legislative texts. p. 500-505.

${ }^{56}$ MEYER, Heinz e SUNTRUP, Rudolf, Lexikon der mittelalterlichen Zahlenbedeutungen. Munique: Wilhelm Fink, 1987 (Münstersche Mittelalter-Schriften, 56), col. 659; 1 coríntios, XIII, 4-7; Conto de Amaro, §8, p. 272-273. Aliás, talvez não seja despropositado pensar que o Flor de Donas da narrativa tenha sido calcado em uma fundação feminina de Alcobaça chamada pela documentação de fins do século XIII de Donas de Cós.

${ }^{57}$ Respectivamente, Gênese, II, 15; Capitula, XV,2, p. 410, Instituta, V, 2, p. 459; Charles OURSEL, Miniatures cisterciennes, 1109-1134. Mâcon: Protat, 1960; Conto de Amaro, §15, p. $280-281$. 
equivalia no plano histórico à prática cisterciense de transplantar as melhores espécies de árvores de um mosteiro (ou Éden simbólico) a outros.

Não só há fortes indícios da origem cisterciense do Conto de Amaro, como também da sua procedência específica, alcobacense. É o caso da atividade desbravadora e povoadora de Amaro, típica dos monges cistercienses, inclusive dos de Alcobaça, que ao longo dos séculos XIII-XIV expandiram bastante seu couto inicial e deram origem a várias povoações. Antes de seguir em direção ao Paraíso, Amaro pediu a seus companheiros para povoarem a região na qual haviam desembarcado. Ele próprio ao descer da montanha edênica não voltou à sua região de origem, como faziam quase todos os que visitavam o Paraíso terrestre, e levantou ali perto a cidade de Trevilles. Esta foi criada entre os vales de três rios (daí seu nome), assim como Alcobaça tinha sido erguida entre um lago marítimo então existente e os vales dos rios Alcoa e Baça (daí o nome da abadia) ${ }^{58}$. A alta produtividade agrícola dessas terras na época em que o manuscrito do conto foi copiado (8 a 13 por semente plantada nos solos férteis), parece ter sido o modelo histórico atribuido às terras de Trevilles ${ }^{59}$. Se excluirmos os verbos abstratos (haver, poder, querer, saber, ser, etc) ou de conotação religiosa (beijar, benzer, cantar, chorar, etc), um dos mais usados no Conto de Amaro é "povoar", com oito ocorrências. Nada estranho, quando se lembra que Alcobaça

${ }^{58}$ NATIVIDADE, Manuel Vieira, O mosteiro de Alcobaça (notas históricas). Coimbra: Progresso, 1885, p. 8, sugeriu a possibilidade inversa, de que o nome Alcobaça (vindo do árabe Al cobaxis, o carneiro) estivesse na origem dos nomes dos rios, hipótese pouco aceita atualmente. De qualquer maneira, como toda igreja cisterciense a de Alcobaça foi dedicada à Virgem, e embora não fosse fenômeno antroponímico exclusivo dos domínios alcobacenses, não é inútil notar que no período 1370-1400 (provavelmente o de elaboração do Conto de Amaro) "Maria" nomeou quase 39\% das mulheres nas terras da abadia, cf. GONÇALVES, Iria, Antroponímia das terras alcobacenses nos fins da Idade Média. Do tempo e da história (Lisboa), 5, 1972, p. 173.

${ }^{59}$ OLIVEIRA MARQUES, António Henrique de, Introdução à história da agricultura. Lisboa: Cosmos, 1968, p. 46-48; GONÇALVES, Iria, O património do mosteiro de Alcobaça nos séculos XIV e XV. Lisboa: Universidade Nova, 1989, p. 242-243; Conto de Amaro, §15, p. 281. Apesar das dificuldades dos séculos XIV-XV, Cister continuou sendo a mais rica ordem monástica em Portugal, cf. OLIVEIRA MARQUES, Portugal na crise dos séculos XIV e XV. Lisboa: Presença, 1987, p. 392. Para SERRÃO, Joaquim Veríssimo, História de Portugal, 1080-1415 [1977]. Lisboa: Verbo, 4ª ed. 1990, Alcobaça “era, sem dúvida, a terra agrícola mais produtiva no conjunto do reino" (p. 176). 
possuía nos seus domínios quinze povoações e cinco portos marítimos ${ }^{60}$. Nos séculos XIII-XIV a abadia tinha acesso direto ao mar e esteve envolvida em atividades marítimas, já se tendo inclusive defendido que muitos dos navios usados nos descobrimentos portugueses foram construídos nos estaleiros de Pederneira, em terras de Alcobaça ${ }^{61}$.

Até mesmo em detalhes arquitetônicos é possível entrever no Conto de Amaro a influência de Alcobaça. A tenda que o personagem encontra pouco antes de alcançar o castelo do Paraíso tem "arcos toda aa rredor", talvez inspirados nas impressionantes galerias com arcos ogivais do recente claustro de Alcobaça, concluído em princípios do século XIV. Os lavabos localizados no lado norte desse claustro podem ter estado na origem da formulação literária "estavã dentro [da tenda, isto é, do claustro] quatro fontes muy bellas e muy preciosas e eram lavradas de metal, e saya a augua per senhas bocas de lyoões" ${ }^{2}$. O alpendre que antecede a porta edênica é de "abóbada muito alta" diz o autor anônimo, como as das naves de Alcobaça, que chamavam atenção pelo fato de a altura das colaterais rivalizar com a da central - quase 19 metros num caso, pouco mais de 20 no outro - enquanto no restante da arquitetura cisterciense aquelas têm usualmente metade da elevação desta. O castelo paradisíaco apresentado pelo texto é de mármore talvez porque assim são as 26 colunas que sustentam a abóbada de Alcobaça. Assim como a maioria dos moinhos de Alcobaça eram hidráulicos, os de Flor de Donas também ${ }^{63}$.

Mais um indício é a já mencionada articulação de Trevilles com outra terra utópica, o império do Preste João. A descrição desse mundo maravilhoso feita

${ }^{60}$ A informação do número de povoações é de COCHERIL, Maur, L'implantation des abbayes cisterciennes dans la péninsule ibérique. Anuario de Estudios Medievales (Barcelona), 1, 1964, p. 276; a da quantidade de portos de GONÇALVES, O património, p. 271. NATIVIDADE, O mosteiro de Alcobaça, p. 117, fornece números um pouco diferentes, treze povoações e dois portos.

${ }^{61}$ GONÇALVES, O património, p. 277; MARQUES, Os coutos de Alcobaça: das origens ao século XVI. em Estudos sobre a Ordem de Cister em Portugal, p. 182 e 188.

${ }^{62}$ Conto de Amaro, §13, p. 277. Talvez não seja inútil lembrar que dentre as particularidades da missa cisterciense está o fato de no momento do Lavabo (rito da missa antes da prece das oferendas) tanto o sacerdote quanto o diácono e o subdiácono lavarem as mãos: Usus antiquiores ordinis cisterciensis, II, 53 (PL 166), col. 1425a. Tal rito foi inspirado pelo Salmo XXV, 6-7: "Lavabo inter innocentes manus meas, et circumdabo altare tuum, Domine; ut audiam vocem laudis, et enarrem universa mirabilia tua".

${ }^{63}$ GONÇALVES, O património, p. 116-121; Conto de Amaro, §11, p. 275. 
por um texto da década de 1160 foi copiada em Alcobaça dois séculos mais tarde, paralelamente à elaboração do Conto de Amaro $^{64}$. A epístola joânica explica que uma das províncias do império é atravessada por um rio que sai do Éden e traz nas suas águas muitas pedras preciosas. Como no conto a montanha do castelo do Paraíso é cortada pelos rios que partem de suas torres, podemos verossimelmente deduzir que "as muitas pedras preciosas" que decoram a edificação existente um pouco mais abaixo, no meio da encosta, provinham de um ou outro daqueles $\operatorname{rios}^{65}$. A epístola localiza a referida província "non longe a Paradiso unde Adam fuit expulsus", o conto coloca a cidade fundada por Amaro em um triplo vale por onde corriam três grandes rios que apesar de não estarem nomeados provavelmente desciam da montanha edênica situada lá perto ${ }^{66}$.

Considerando que Amaro retornou ao Porto de Quatro Casas menos de 25 dias depois de ter partido dali em direção ao Éden, 16 dos quais ficou em Flor de Donas e um na casa de santos ermitões, considerando que Trevilles foi erguida "muito perto" de Flor de Donas, que ficava a somente um dia de marcha da montanha edênica ${ }^{67}$, pode-se pensar que a terra amariana estava localizada em território joânico. Esta hipótese reforça as razões da visita que em 14 de maio de 1425 o infante D. Pedro fez mais uma vez a Alcobaça, antes de começar viagem que se estenderia até 1428 e graças à qual obteve informações adicionais sobre as terras do Preste João ${ }^{68}$. De acordo com

${ }^{64}$ Lisboa, Biblioteca Nacional de Portugal, cod. Alc. CCLVI / 380, fol. 84r-87r; OTO DE FREISING, Chronica sive Historia de duabus Civitatibus / Chronik oder die Geschichte der Zwei Staaten. VII, 33, ed. Adolf Hofmeister e Walther Lammers, trad. Adolf Schmidt, Berlim: Rütter und Loening, 1960, p. 556-559. Sobre o caráter utópico desse império, cf. nosso La construction d'une utopie: l'empire de Prêtre Jean. The Journal of Medieval History (Oxford), 23, 1997, p. 211-225 (traduzido em A Eva barbada. Ensaios de mitologia medieval, São Paulo: Edusp, 2010, p. 85-102).

${ }^{65}$ De India et de eius mirabilibus, §5, p. 290, linhas 48-51; Conto de Amaro, §13, p. 277.

${ }^{66}$ De India et de eius mirabilibus, §6, p. 290, linhas 70-71; Conto de Amaro, §15, p. $280-281$.

${ }^{67}$ Conto de Amaro, §14, p. 280; §11, p. 275; §10, p. 273-274; §15, p. 280; §11, p. 276.

${ }^{68}$ GÓMEZ DE SANTISTEBAN, Libro del infante Don Pedro de Portugal. ed. Francis Rogers, Lisboa: Fundação Calouste Gulbenkian, 1962. A descrição do império do Preste João nesse texto do último terço do século está nos capítulos 16-21, p. 38-56. A viagem do infante está na origem do mapa encomendado por D. Afonso V a Fra Mauro (1460) e usado por D. João II para elaborar o chamado Plano da Índia, cf. MARQUES, Alfredo Pinheiro, Vida e obra do infante Dom Pedro. Lisboa / Figueira da Foz / Mira: Centro de Estudos do Mar Luís de Albuquerque / Câmara Municipal de Mira / Gradiva, 1996, p. 100-109. 
Vitorino Magalhães Godinho, em algumas cidades por onde D. Pedro passou (caso de Veneza, Ferrara, Roma e Barcelona) a origem africana do Preste João era admitida, o que deve ter influenciado as navegações promovidas por seu irmão D. Henrique, o Navegador, que tinha como um de seus objetivos declarados dobrar o cabo Bojador, pois "passara por ali São Brandão"69. Ou seja, personagem que como Amaro tinha saído em busca do Paraíso terrestre, viagem descrita por texto muito popular do qual se conhece 117 manuscritos latinos, inclusive um copiado no século XIV em Alcobaça ${ }^{70}$.

Ainda mais significativa é a conexão textual com $A$ demanda do santo Graal, do último quartel do século XIII, tradução em que transparece a supremacia do sacerdócio da virtude sobre o sacerdócio oficial, o que já foi visto como reflexo do pensamento do cisterciense Joaquim de Fiore, introduzido em Portugal pelos seus colegas de Ordem ${ }^{71}$. Foi aquele monge calabrês que, em fins do século XII, tinha anunciado uma próxima Idade do Espírito Santo, cujo inaugurador seria Galaaz e cuja Igreja seria representada por Josefes, bispo sagrado diretamente por Deus por ser filho de José de Arimatéia, o personagem que recolhera o sangue de Cristo no Graal. Por ter sido no Pentecostes que apareceu aos cavaleiros da Távola Redonda, o Graal era forma visível do Espírito Santo, que segundo o conto foi quem enviou Amaro às portas do Paraíso - "eu bem sei que tu nõ vieste aquy se nõ pello Spiritu Sancto", diz o porteiro do Éden ao santo homem ${ }^{72}$. Do Paraíso,

Não é inútil lembrar que o original do mapa-múndi de Fra Mauro foi enviado a Alcobaça (cf. CORTESÃO, Armando, History of Portuguese Cartography. Coimbra/Lisboa: Universidade de Coimbra / Junta de Investigações do Ultramar, 1971, vol. II, p. 174), comprovando a um só tempo a ligação da abadia com a monarquia e com a navegação marítima.

${ }^{69}$ GODINHO, Mito e mercadoria, utopia e prática de navegar. Séculos XIII-XVIII. Lisboa: Difel, 1990, p. 166; GOMES EANES DE ZURARA, Crónica do descobrimento e conquista da Guiné, I, 7, ed. José de Bragança, Lisboa: Civilização, 1937, p. 60.

${ }^{70}$ SELMER, Carl, The Lisbon Vita Sancti Brandani Abbatis. A hitherto unknown Navigatio-text and translation from Old French into Latin. Traditio (Nova York), 13, 1957, p. 313-344. Esta versão e outras duas reduzidas, copiadas em Coimbra, foram recentemente estudadas, editadas e traduzidas por NASCIMENTO, Navegação de S. Brandão, citado na nota 7.

${ }^{71}$ La Queste del Saint Graal, roman du XIIIe siècle. ed. André Pauphilet, Paris: Honoré Champion, 1980; Demanda, edição citada na nota 17. Sobre a influência do joaquimismo nesse texto, BRUNETI, Almir de Campos, A lenda do Graal no contexto heterodoxo do pensamento português. Lisboa: Sociedade de Expansão Cultural, 1974.

${ }^{72}$ Demanda, IV, 25, p. 38; Conto de Amaro, §13, p. 279. 
Amaro saiu com uma porção de terra numa escudella, palavra do século XIII vinda do latim scutella, diminutivo de scuta, "gamela", por sua vez derivada, no mesmo século, de camella, "vaso de madeira usado em certos sacrifícios", como de certa forma era o graal da Demanda, cálice usado na Última Ceia e que teria recolhido o sangue de Cristo crucificado. Também não é inútil lembrar que na versão de Wolfram von Eschenbach, dos primeiros anos do século XIII, o Graal é guardado pelos templários, monges-guerreiros cuja regra foi inspirada por São Bernardo, que chamava de optimum castrum seu mosteiro de Claraval - cuja planta, invertendo-se apenas a posição da igreja em relação ao claustro, foi copiada em Alcobaça - o que já permitiu identificá-lo com o castelo do Graal ${ }^{73}$.

Não se deve esquecer que os monges alcobacences, tudo indica, estiveram na origem ou ao menos inspiraram a tradução portuguesa de $A$ demanda do santo $\mathrm{Graal}^{74}$, hoje conhecida por meio de um manuscrito do século XV, contemporâneo ou quase ao do Conto de Amaro. Ora, entre a monarquia e Alcobaça havia estreita relação na época da confecção do relato sobre Amaro $^{75}$, relação simétrica à existente entre a monarquia e a figura central da Demanda, Galaaz. No complexo mítico-ideológico de então, o rei D. João I ficava identificado ao modelo monárquico de Artur e o condestável D. Nuno Álvares Pereira ao modelo cavaleiresco e casto de Galaaz ${ }^{76}$.

${ }^{73}$ Sermones, III, 3 (S.Bernardi opera, V), p. 381, linha 15; GRILL, Léopold, Château du Graal: Clairvaux. Analecta Sacri Ordinis Cisterciensis (Roma), 17, 1961, p. 115-126.

${ }^{74}$ É numa "abadia de monges brancos" que estava guardado atrás do altar o escudo branco com uma cruz vermelha pintada pelo sangue de Josefes, peça destinada a Galaaz: Demanda, VIII, p. 59-66.

${ }^{75}$ Exemplo disso é D. Pedro I ter, em 1358, restituído àquele mosteiro os direitos senhoriais contestados por seu pai, bem como o mesmo monarca ter sido ali sepultado em 1367. A ligação acentuou-se sob D. João I, quando o abade D. João de Ornelas para ajudar o rei na decisiva batalha de Aljubarrota (1385) enviou víveres e um corpo auxiliar, comandado por seu irmão, para impedir a retirada dos castelhanos. Naquela abadia o rei fez sepultar com todas as honras os fidalgos portugueses mortos na batalha. Aliás, foi D. João I que imporia D. Estevão de Aguiar como abade de Alcobaça (1431-1446).

${ }^{76}$ Os modelos literários do rei e do condestável são transmitidos por FERNÃO LOPES, Crónica de D. João I. ed. Anselmo Braamcamp Freire, Porto: Civilização, 1991, I, 34, vol. I, p. 69; I,193, vol. I, p. 424-427; II,75, vol. II, p. 186; Estoria de Dom Nuno Alvrez Pereyra. 4, ed. Adelino de Almeida Calado, Coimbra: Universidade de Coimbra, 1991, p. 8, linhas 17-26. Sobre o entrecruzamento dos dois personagens, COELHO, Maria Helena da Cruz, D. João I, o que re-colheu Boa Memória. Lisboa: Círculo de Leitores, 2005. Não é sem interesse assinalar a presença cisterciense nesses modelos mesmo na longa duração 
Na geração seguinte, o infante D. Henrique, virgem, casto e piedoso no dizer de vários cronistas (dentre eles Zurara, João de Barros e Pedro Álvares Seco), portanto discípulo espiritual de Nuno Álvares, não estaria igualmente buscando o Graal? De toda forma, na sua época ainda se acreditava que além-Bojador ficava o "mar tenebroso" e a sudoeste dos Açores o "mar de sargaço" (isto é, de algas) que não deixavam de ter relação com o "mar pantanoso" enfrentado por Brandão, o "mar arenoso [que] ninguém pode atravessar" referido pela epístola do Preste João, o "maar cõ tormẽta" que Amaro defrontou logo depois de partir e o "mar quoalhado" encontrado por ele bem adiante do mar Vermelho ${ }^{77}$. Não é mera coincidência que o conto fale numa ilha Deserta, que na Demanda exista uma cidade chamada Deserta, que nas Canárias descobertas em 1336 e bem conhecidas na segunda metade do século haja uma ilha Deserta, que a epístola do Preste João se refira à "deserta" Babilônia ${ }^{78}$. A época foi de, fenômenos intimamente entrecruzados, demanda do Paraíso, demanda do Graal, demanda do Preste João.

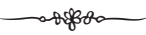

Sendo a participação humana, de acordo com alguns estudiosos ${ }^{79}$, decisiva na construção de uma utopia, poder-se-ia hesitar em atribuir tal qualificativo

histórica, como mostra um historiador alcobacense da primeira metade do século XVIII ao comparar D. Nuno a São Bernardo: SANTOS, Manoel dos, Monarquia Lusitana. VIII, 47, Lisboa: Imprensa Nacional-Casa da Moeda, 1988, p. 484.

${ }^{77}$ Respectivamente, BENEDEIT, Nauigatio Sancti Brandani, ed. Nascimento, 12/13, p. 160-161 e 14/16, p. 164-165; De India et de eius mirabilibus, §7, p. 290, linhas 78-80; Conto de Amaro, §2, p. 265 e $\$ 5$, p. 267.

${ }^{78}$ Conto de Amaro, §6, p. 269; Demanda, LVI,399, p. 384; CORTESÃO, History of Portuguese Cartography. p. 68-76; De India et de eius mirabilibus, §4, p. 289, linha 35, §11, p. 292, linha 131. Note-se ainda que no conto o importante personagem Leomites, monge de Vale de Flores, é identificado como "natural de Babilônia, a deserta" (§7, p. 270).

${ }^{79}$ Dentre eles, CIORANESCU, Alexandre, Utopie: cocagne et âge d'or. Diogène (Paris), 75, 1971, p. 92 ; TROUSSON, Raymond, Voyages aux pays de nulle part. Histoire littéraire de la pensée utopique, [1975]. Bruxelas: Éditions de l'Université de Bruxelles, 3ª ed. 1999, p. 21; MANUEL, Frank e Fritzi, Utopian thought in the western world. Cambridge (Mass.): Belknap Press of Harvard University Press, 1979, p. 112; ELIAV-FELDON, Miriam, Realistic Utopias : the imaginary societies of the Renaissance, 1516-1630. Oxford: Clarendon, 1982, p. 2; HUGUES, Micheline, Émergence de l'utopie. em THOMASSET, Claude e JAMES-RAOUL, Daniele (org.), En quête d'utopies. Paris: Presses de l'Université Paris-Sorbonne, 2005, p. 384. 
à cidade de Amaro, já que em toda a trajetória do personagem as intervenções divinas revelam-se decisivas. Dever-se-ia, então, simplesmente taxar o conto de hagiográfico. Mas é possível objetar, acompanhando Arrigo Colombo e Jean-Claude Besson-Girard, que foi com o mito do Paraíso que surgiu a noção de utopia ${ }^{80}$. Realmente, quando D. Manuel afirma em carta aos Reis Católicos, de 28 de agosto de 1501, que "Nosso Senhor milagrosamente quis que se achasse [o Brasil] porque é mui conveniente e necessária à navegação da Índia”, ele não nega que naquele evento tinha havido além da intervenção divina muito empenho humano ${ }^{81}$.

O Conto de Amaro é boa ilustração disso. Sua frase de abertura revela o "grande desejo" de o personagem ver o Paraíso terreno, e se a seguir uma voz lhe explica que Deus "quer cumprir teu rogo e desejo", logo depois o autor esclarece que isso não se faria sem "grande esforço", e para realizá-lo Amaro teve "esperança". A frase de fecho confirma que o sucesso não decorreu apenas da ajuda divina: "assy acabou Amaro o que desejava polla graça e esforço que em Deus tomou". No total, o relato recorre doze vezes à palavra "desejo" e seus derivados, que aparecem portanto em média uma vez a cada dois fólios. Este fato parece corroborar a proposta de Ernst Bloch, que vê a origem de toda utopia no desejo ("pai do pensamento", Vater des Gedankens) e na espera ativa ("princípio esperança", Prinzip Hoffnung) ${ }^{82}$ Não são os milagres que definem a trajetória e a obra de Amaro. É o desprendimento demonstrado por ele logo no início da narrativa (doa muitos bens aos pobres) que lhe permite alcançar a fartura final (torna-se senhor de uma grande e rica cidade). Mais do que um predestinado, Amaro é alguém cuja conduta fizera por merecer os favores do Céu. Assim como no Paraíso Adão tinha sido "incola felix", em Trevilles Amaro foi feliz cuidando daquela região "tam bõoa" graças à terra que trouxera do Paraíso e que "cheirava

${ }^{80}$ COLOMBO, L'utopia. Rifondazione di un'idea e di una storia. Bari: Dedalo, 1997, p. 92-94; BESSON-GIRARD, Du labyrinthe au paradis, ou la tentation utopiste. Entropie. Revue d'étude théorique et politique de la décroissance (Lyon), 4, 2008, p. 20 e 26.

${ }^{81}$ Reproduzida e transcrita por DIAS, Carlos Malheiros, A semana de Vera Cruz. em IDEM (dir.), História da colonização do Brasil. Porto: Litografia Nacional, 1923, vol. II, p. 155 e 165 .

${ }^{82}$ Conto de Amaro, §1-2, p. 265 e §15, p. 281; BLOCH, Das Prinzip Hoffnung [1959], 41, Frankfurt: Suhrkamp, 1985 (Werkausgabe, 5), p. 1018. 
mais e melhor que todas as coisas do mundo" $"$. Realizava-se ali a antiga observação de Horácio - se a Idade de Ouro não existe mais aqui, deve ser buscada acolá, deve-se descobrir "no oceano que nos circunda e espera" locais que vivem no presente como se vivia no passado, terras distantes e desconhecidas reservadas por Júpiter "a um povo piedoso", piae genti, como seriam também os utopianos ${ }^{84}$.

Destarte, o que o Conto de Amaro transmite não é um simples relato maravilho, gênero ao qual os portugueses medievais aparentemente não eram muito afeitos. De acordo com o que escreve em 1539 o cronista João de Barros, Colombo não teve aceitação na corte portuguesa por ter fundado seu projeto "fantástico e de imaginações" no livro de Marco Polo. Camões em 1572 criticou a mentalidade demasiado imaginativa tanto de antigos (as "fábulas vãs" sobre calipsos e harpias) quanto de medievais (as façanhas "fantásticas, fingidas, mentirosas" de Rolando) ${ }^{85}$. De fato, no Conto de Amaro há somente cinco passagens que tratam de eventos maravilhosos, quer dizer, na definição dada pelo inglês Gervais de Tilbury por volta de 1214, "aquilo que escapa à nossa compreensão, embora seja natural" ".6. Ademais, pelo menos uma daquelas passagens do conto é de raízes claramente literárias. Tudo indica que o monge anônimo inspirouse em Homero no episódio do navio de Amaro encalhado, cercado por monstros marinhos carnívoros e tirado daquela situação pelas próprias bestas

${ }^{83}$ Citações de MILON DE ELNO, De sobrietate, I, 5, ed. Ludwig Traube (MGH. Poetae Latini Carolini, 3), p. 619, linha 130; Conto de Amaro, §15, p. 280-281.

${ }^{84}$ Epode, 16, ed. David Mankin, Cambridge, CUP, 2002, p. 43-45 (citações, v. 41, p. 44; v. 63, p. 45); TOMÁS MORE, Utopia. II, Basiléia: Jean Froben, $4^{\mathrm{a}}$ ed. 1518, edição facsimilada e traduzida por PRÉVOST, André, Paris: Mame, 1978, p. 105, linhas 24-25.

${ }^{85}$ BARROS, João de, Ásia. Dos feitos que os portugueses fizeram no descobrimento e conquista dos mares e terras do Oriente. I, III, 11, ed. Hernani Cidade, Lisboa: Agência Geral das Colônias, 1945, p. 120; CAMÕES, Os Lusíadas, ed. Hernani Cidade, Lisboa: Sá da Costa, 1956 (Obras Completas, 4), I,11:2, p. 8 e V, 89:6, p. 290. Duas importantes autoridades historiográficas também assinalam a pequena propensão lusitana ao maravilhoso: BUARQUE DE HOLANDA, Sérgio, Visão do Paraíso [1959]. São Paulo: Brasiliense / Publifolha, 2000, p. XI, XVIII-XIX, XXII, 1-17, 161-182; MAGALHÃES GODINHO, Mito e mercadoria. p. 95 e 78-79.

86 "Mirabilia constituit ignorantia reddende rationis quare sic sit": TILBURY, Gervásio de, Otia imperialia. III, Prefácio, ed.-trad. S. E. Barks e James W. Binns, Oxford: OUP, 2002 (Oxford Medieval Texts), p. 559. 
que puxam o navio ao lutarem com odres cheios de vento jogados ao mar pela tripulação ${ }^{87}$.

Como estamos sugerindo neste estudo, o Conto de Amaro pode ser entendido como uma versão literária da utopia cisterciense em geral e alcobacense em particular. Utopia que passava por dificuldades com a retração geral da mão-de-obra decorrente da inversão da tendência demográfica nas últimas décadas do século XIII, fortemente acentuada pela Peste Negra - a população portuguesa recuou de milhão e meio de indivíduos a um milhão ou mesmo menos; a população monástica em apenas dois meses de 1348 perdeu 150 indivíduos $^{88}$. A Ordem Cisterciense foi assim atingida no seu fundamento econômico, a utilização de conversi, categoria de servidores de baixo custo (celibatários, não tinham família a sustentar) e grande dedicação (ingressavam espontaneamente na Ordem) que até fins do século XIII ou mesmo meados do XIV tinha sido mais numerosa que a dos monges ${ }^{89}$. Para compensar essa queda, a Ordem criou a instituição dos familiares (também chamados de donati ou oblati), gente de estatuto intermediário entre trabalhadores contratados e conversos, devotos laicos que portavam vestes seculares e não faziam votos vitalícios, apenas prometiam obediência ao abade, efetivo que em 1293 o Capítulo Geral constatava existir em "número excessivo" 90

${ }^{87}$ Conto de Amaro, §5, p. 267-268. Na Odisséia, o deus Éolo enche um odre de vento e coloca-o no barco de Ulisses, cuja tripulação libera aos pouco o vento até chegar em alto mar (X,1-75, ed. Alfred Heubeck, trad. G. Aurelio Privitera, Milão: Fondazione Lorenzo Valla / Arnoldo Mondadori, 1983, vol. III, p. 51-57).

${ }^{88}$ A estimativa populacional global é de OLIVEIRA MARQUES, Portugal na crise dos séculos XIV e XV. p. 49, 16-21. A mortandade de monges é fornecida por SÃO BOAVENTURA, Historia chronologica. p. 178, e adotada por DIMIER, Ansèlme, L'art cistercien hors de France. La Pierre-qui-Vire: Zodiaque, 1971, p. 258.

${ }^{89}$ COCHERIL, Maur, Alcobaça. em ANDRADE, António Alberto Banha de (dir.), Dicionário de História da Igreja em Portugal. Lisboa: Resistência, 1980, vol. I, p. 104, estima que no seu apogeu Alcobaça deve ter tido entre 150 e 170 monges para 200 a 250 conversos. A retração no número de conversos em Alcobaça é praticamente unânime na historiografia, por exemplo BARBOSA, Pedro Gomes, Cistercienses. em AZEVEDO, Carlos Moreira (dir.), Dicionário de História Religiosa de Portugal. Lisboa: Centro de Estudos de História Religiosa da Universidade Católica Portuguesa / Círculo de Leitores, 2000, vol. I, p. 348 .

${ }^{90}$ LEKAI, The Cistercians. p. 337-344. A avaliação do Capítulo Geral é citada pelo mesmo autor à p. 379 . 
Enquanto nos primeiros tempos de sua história "Cister queria agir pelo exemplo", avalia Duby, no século XIV que viu baixar o padrão ascético dos monges brancos, informa Lekai, inclusive em Alcobaça, completa Gusmão ${ }^{91}$, o relato sobre a aventura de Amaro talvez quisesse revigorar e difundir os tradicionais valores cistercienses. É verdade que o estatuto do personagem aparece de forma ambígua no conto. Ele nunca é definido como monge, há mesmo indícios de que não era. Por outro lado, não é impossível que o fosse ${ }^{92}$. Testemunham a favor dessa hipótese vários elementos. Um, logo no começo do relato Amaro é chamado de homem bõo, expressão que por muito tempo foi (embora não exclusivamente) sinônimo de "frade" e de "ermitão". Dois, o fato de ele começar a aventura doando seus bens aos pobres, como deveria fazer todo monge: em carta a São Bernardo, que ele sabia compartilhar a idéia, Pedro Venerável pergunta de forma retórica "que significa a frase 'dê tudo que tens aos pobres e siga-me', senão faça-te monge?” Três, Valides diz a Amaro que gostaria de colocar sua sobrinha "em na hordem [...] e que rrecebesse ella o avito da tua maão sancta", o que efetivamente aconteceu dias depois. Quatro, pouco antes de se dirigir à montanha paradisíaca Amaro recebeu como lembrança da sobrinha de Valides "huĩa vestidura muy rryca, branca como a neve [...] e el vestyo chorando e beenzeo a". Quinto, é esse mesmo hábito branco distintivo dos cistercienses que ele vestia diante do Paraíso e foi elogiado pelo porteiro: "teus panos que som muy fremosos" 93 .

Poder-se-ia contrargumentar que se fosse monge, Amaro não teria fundado uma cidade e sim um mosteiro. Mas se este é sempre rural, remete à idéia do eremus patrístico, não deixa na Idade Média de servir de modelo para as cidades, muitas vezes "construídas segundo um tipo de geografia

${ }^{91}$ DUBY, Saint Bernard, l'art cistercien. p. 100; LEKAI, The Cistercians, p. 370 e 373; GUSMÃO, Artur, A real abadia de Alcobaça. Lisboa: Ulisséia, 1948, p. 49-50. SÃO BOAVENTURA, Historia chronologica. p. 10, coloca no século XV a inobservância das regras monásticas.

${ }^{92}$ Recentemente negamos essa possibilidade ("Concepts of time”, p. 64), que novas releituras do texto nos levam a rever, pelos motivos que se dirá a seguir.

${ }^{93}$ Para o primeiro argumento, VITERBO, Joaquim de Santa Rosa de, Elucidário das palavras, termos e frases que em Portugal antigamente se usaram [1798-1799]. ed. Mário Fiuza, Porto / Lisboa: Civilização, 1984, vol. II, p. 286. Para o segundo, PEDRO VENERÁVEL, Epistolarium, I, 28 (PL 189), col. 117d. Para os demais, Conto de Amaro, $\S 11$, p. 275-276; §13, p. 279. 
monástica melhorada e adaptada, assim como suas constituições se inspiram frequentemente em regras monásticas”, observa Séguy. Ademais, é preciso acrescentar, todo mosteiro é funcionalmente uma microcidade, que no plano externo tem personalidade jurídica coletiva, no plano interno legislação, dirigentes, serviçais, oficinas, zona rural. Poder-se-ia contrargumentar também, que se fosse monge Amaro deveria estabilidade e não teria viajado quase escondido ("nõ digas a nenhũu nenhũa cousa de teu feito nẽ pera hu vaas"), mas - é novamente Séguy que o lembra com razão - os cistercienses faziam "passar a consciência individual antes da obediência devida aos superiores, segundo Romanos XIV, 3, tendência de que São Bernardo se fará porta-voz" ${ }^{94}$.

Admitida a possibilidade de Amaro ter sido monge, não é absurdo pensar que seu nome fazia alusão a Mauro, o discípulo predileto de São Bento, cuja regra os cistercienses buscavam revigorar na sua plenitude. Pelo menos foi o que pensou no século XVIII o monge alcobacense que no fólio de rosto do manuscrito deu como título Hystoria de certo homem pio chamado Mauro, o qual depois de perigozos e quazi impraticaveis trances conseguio o desejo que tinh a de ver o paraizo terrestre. Se Amaro foi monge, seus companheiros poderiam ser conversi, sujeitos que apesar da proibição de abandonarem as granjas em que viviam e trabalhavam, em certos casos acompanhavam o abade em viagens. Ademais, eles tinham como uma de suas principais tarefas exatamente a construção civil, o que ajudaria a explicar como no relato transformaram uma região rural em "hũa muy gram cidade" Os companheiros poderiam também ser "moços", categoria de servidores que no abaciado de Estevão Aguiar, quando foi copiado o manuscrito hoje conhecido do Conto de Amaro, representou 12\% do total de viajantes a cargo de Alcobaça, indivíduos que às vezes acompanhavam um religioso em alguma missão. Tanto num caso como noutro, isso elucidaria uma escolha vocabular do texto, qualificar os companheiros de viagem de Amaro como "dezaseis mãcebos grandes e arryzados", sabendo que mancebo indicava justamente gente de condição social inferior e dedicada ao trabalho braçal ${ }^{96}$.

\footnotetext{
${ }^{94}$ SÉGUY, Une sociologie. p. 344 e 351; Conto de Amaro, §1, p. 265.

${ }^{95}$ LEKAI, The Cistercians. p. 337; Conto de Amaro §14, p. 280.

${ }^{96}$ A categoria de "moços" é informada por GONÇALVES, Iria, "Viajar na Idade Média: de e para Alcobaça na primeira metade do século XV”, Estudos Medievais (Porto), 2, 1982,
} 
Em todo caso, qualquer que tenha sido o estatuto jurídico exato de Amaro, é inegável sua simpatia pelos "frades brancos". Assim, o relato significativamente escrito em vernáculo, não em latim - não teria tido como função estimular o recrutamento de novos elementos (conversi ou donati ou moços) face à crescente dificuldade de Alcobaça em fazê-lo? Não seria, portanto, um discurso de fundo utópico diante da nova situação distópica?

p. 15-17. Sobre a acepção de "mancebo", BLUTEAU, Vocabulario, cita o mestre Venegas para quem a palavra deriva de manus e cibo e designa um indivíduo que "por ser robusto se guardava para o trabalho" (vol. 5, p. 280-281). COROMINAS, Joan, Diccionario crítico etimológico castellano e hispánico, Madri: Gredos, 1992, vol. III, p. 818, observa que em castelhano mancebo manteve até meados do século XIII a acepção de escravo. A partir disso poder-se-ia mesmo, talvez, associar o fato literário do número de mancebos de Amaro - que na versão espanhola é indeterminado - com o fato histórico de Alcobaça fornecer anualmente dezesseis cavalos ao rei português (cf. TRILHE, Robert Auguste, "Alcobaça", em Dictionnaire d'Histoire et Géographie Ecclésiastique, Paris: Letouzey et Ané, 1914, col. 26). 